\title{
The Ratification of the New York Convention in Ethiopia: Towards Efficacy and Avoidance of Divergent Paths
}

Tecle Hagos Bahta *

\begin{abstract}
Ethiopia's ratification of the New York Convention for the recognition and enforcement of foreign arbitral awards and arbitration agreements is a welcome development. The Convention has been greatly facilitating cross-border mobility of arbitral awards and arbitration agreements in international commercial transactions. The entry into force of the New York Convention (as of 13 March 2020) and the enactment of the Arbitration and Conciliation Proclamation No.1237/2021 have ushered a relatively new era of modern arbitral regime in Ethiopia. In this regard, the necessary legal and formal infrastructure should be laid down for the proper implementation of the New York Convention. This article examines the ramifications of the three reservations registered by Ethiopia under the Convention; namely, the reciprocity, commercial and the non-retroactive application of the Convention. Furthermore, the multiplicity of enforcement regimes in the Ethiopian arbitral system related to these reservations are expounded. The formality requirements enunciated under the New York Convention are elaborated and the need for setting out the legal and institutional framework for contextualization thereof are dealt with. The possibility for award-creditors to resort to the more favourable local law or treaty other than the New York Convention and the recent trend of recognizing and enforcing arbitral awards, which are set aside or annulled in the place of arbitration are highlighted.
\end{abstract}

\section{Key terms:}

New York Convention · Arbitration · Reciprocity $\cdot$ Recognition and enforcement $\cdot$ Foreign arbitral awards

DOI http://dx.doi.org/10.4314/mlr.v15i2.6

This article is licensed under a Creative Commons Attribution-NonCommercialNoDerivs (CC BY-NC-ND)

Received: 30 July 2021

Accepted: 6 December 2021

* Tecle Hagos Bahta, (LL.B, LL.M), Senior Lecturer of Law, University of Botswana, Department of Law; formerly Associate Professor of Law, Mekelle University, School of Law. Email: teclehaba@gmail.com

ORCID: https://orcid.org/0000-0002-2533-4694

The author wishes to thank the two anonymous reviewers for their valuable comments on the earlier draft of this work. 


\section{Suggested citation:}

Tecle Hagos Bahta (2021), 'The Ratification of the New York Convention in Ethiopia: Towards Efficacy and Avoidance of Divergent Paths', 15(2) Mizan Law Re view: 493-522

\section{Contents}

Abstract

1. Introduction

2 The Multiplicity of the Enforcement Regimes

2.1 Nationality of arbitral awards

2.2 Multiple enforcement regimes: à la carte

3. 'Reservations' under the New York Convention

3.1 Retroactive application of the Convention

3.2 Date of entry into force of the New York Convention in Ethiopia

3.3 Reciprocity reservation

3.4 Commercial reservation

3.5 Formality requirements and national treatment of foreign arbitral awards

4. The Enforcement of Annulled Arbitral Awards in Their Country of Origin

5. Conclusion

\section{Introduction}

International trade and investment cannot be contemplated without speedier, less costlier, impartial and independent dispute resolution mechanisms. Arbitration and conciliation/mediation have been significantly featuring in the dispute settlement processes of international commercial and investment disputes. Of these two, arbitration has been the most acceptable and widely recognized dispute settlement mechanism. As Samuel K.B. Asante stated: ${ }^{1}$

\section{Frequently used acronyms}

BITs Bilateral investment treaties

COMESA Common Market for Eastern and Southern Africa

ICSID International Center for the Settlement of Investment Disputes

MIAs Multilateral investment agreements

UNCITRAL United Nations Commission on International Trade Law

${ }^{1}$ Amazu A. Asouzu (2001), International Commercial Arbitration and African States: Practice, Participation and Institutional development, CUP, p. xiii. 
[...] African governments and private parties involved in negotiating international business transactions such as loan agreements, petroleum and mining agreements, industrial joint ventures, management agreements, international procurement contracts, international supply contracts, bilateral or international trade agreements and bilateral investment agreements have come to the realization that foreign parties to these transactions, i.e., foreign governments, transnational corporations, international banks, foreign investors, international suppliers and contractors, all insist on an appropriate dispute settlement mechanisms, which is invariably international arbitration.

He further stated: ${ }^{2}$

Such parties predominantly prefer international arbitration because of the strong perception that an international forum for settling disputes provides some insurance against possible bias by a national judiciary. Thus, African countries caught in the web of a plethora of international transactions recognize the virtual inevitability of accepting international commercial arbitration. Indeed, the acceptance of international arbitration has become an invariable ingredient of the liberalization packages which African countries, and developing countries elsewhere, provide as a sine qua non of their strategies to attract foreign investment and technology, international finance and foreign trade.

Arbitration, therefore, has been preferred to conciliation/mediation particularly because arbitral awards have been successful in their mobility across borders. Notwithstanding the recent efforts to make conciliation/ mediation more effective through the Singapore Convention on Mediation, ${ }^{3}$ their efficacy in terms of their international enforceability has been limited. In contrast, international mobility has enabled arbitral awards to be recognized and enforced with ease not only because arbitration has been accepted as the favourable dispute settlement for trade and investment but also because of the coming into effect of the New York Convention for the

\footnotetext{
${ }^{2}$ Ibid.

${ }^{3}$ See United Nations Convention on the international Settlement Agreements Resulting from Mediation (The Singapore Convention on Mediation), available at $<$ https://uncitral.un.org/en/texts/mediation/conventions/international_settlement_agree ments $>$ Last accessed on 20/12/2021.
} 
Recognition and Enforcement of Foreign Arbitral Awards of $1958 .{ }^{4}$ The New York Convention has been hailed as the most successful convention relative to commercial matters.

Ethiopia has become party to the New York Convention since March $2020 .{ }^{5}$ This is aimed to facilitate the inflow of foreign direct investment into Ethiopia and lubricate the wheels of commercial arbitration agreements and the reciprocal recognition and enforcement of foreign arbitral awards. ${ }^{6}$ This effort is also accompanied by a new arbitration and conciliation proclamation, ${ }^{7}$ which is believed to help the country become a hub for arbitration.

In this respect, this article generally deals with the essential underpinning legal infrastructure that are requisite for the smooth application of the New York Convention in the Ethiopian legal system. It also highlights the context in Ethiopia under which the New York Convention is to operate. It is not intended to deal with all the requirements (conditions) for the refusal of foreign arbitral awards, which are put in place under the New York Convention; the grounds for refusal, as set out under Article V of the New York Convention, are better dealt with in the light of their practical applications in the future aided by judicial and arbitral cases.

The article introduces the New York Convention in the first two sections. The various applicable set of rules competing for application owing to the coming into force of the New York Convention in Ethiopia are introduced and analyzed. The reservations registered by Ethiopia in the process of accession are discussed and their implications in Ethiopia are explored in the third section. The fourth section deals with the recognition and enforcement

\footnotetext{
${ }^{4}$ The New York Convention on the Recognition and Enforcement of Arbitral awards of 1958 (hereinafter referred to as 'New York Convention'; see text available at https://uncitral.un.org/en/texts/arbitration/conventions/foreign_arbitral_awards (Last accessed on 20/12/2021).

5 The New York Convention Ratification Proclamation No.1184/2020, Fed. Neg. Gaz., Year 26, No.11, 11 March 2020.

${ }^{6}$ For the pros and cons of ratifying the New York Convention by Ethiopia, see Fekadu Petros (2014), 'The Convention on the Recognition and Enforcement of Foreign Arbitral Awards: Advantages, Disadvantages and some Remarks on Ethiopia's Course of Action Ahead', Mizan Law Review, Vol. 8, No. 2, pp. 470-483 (Comment in Amharic); and Mesfin Beyene (2019), 'Towards a Better Commercial Arbitration: Should Ethiopia Ratify the New York Convention', Mizan Law Review, Vol. 13, No.1, pp. 123-152.

${ }^{7}$ The Arbitration and Conciliation Working Procedure Proclamation No.1237/2021, Fed. Neg. Gaz., Year 27, No.21, 2 April 2021 (hereinafter 'Arbitration and Conciliation Proclamation No.1237/2021').
} 
of foreign arbitral awards which are set aside in their country of origin, followed by conclusion.

\section{The Multiplicity of the Enforcement Regimes}

\subsection{Nationality of arbitral awards}

The determination of the nationality of an arbitral award is crucial as the concept and practice of recognition and enforcement of the arbitral award is based on the nationality thereof. There are several bases upon which the nationality of arbitral awards are determined. Under the Civil Procedure Code of Ethiopia. A 'foreign judgment' is defined as the judgment of a foreign court. ${ }^{8}$ By analogy, a 'foreign arbitral award' is meant to be an arbitral award, which is rendered outside of Ethiopia.

This definition is obviously too simplistic. However, for practical purposes, Ethiopian courts did not need to belabour on the issue for two reasons; first, it is required that 'a certificate signed by the President or the registrar of the court having given judgment to the effect that such judgment is final and enforceable' should be submitted to the enforcing court in Ethiopia. ${ }^{9}$ This is what is generally referred to as an 'enforcement order' or exequatur granted by the court of the place where the arbitral award is rendered. Second, judicial practice ${ }^{10}$ shows that the award-creditor is obligated to prove that there exists reciprocity between the two countries as stipulated under Art. 461(1)(a) of the Civil Procedure Code.

Currently, with the promulgation of the new Arbitration and Conciliation Proclamation No.1237/2021, it is set out that the place (seat) of the arbitration is deemed to be where the arbitral award is made. ${ }^{11}$ In this regard, the Proclamation provides the following definition for "foreign arbitral awards':

[...] an arbitral award which is deemed to have been rendered in a foreign country in accordance with international treaties acceded and ratified by Ethiopia or a decision in which the seat of

\footnotetext{
${ }^{8}$ See Civil Procedure Code of Ethiopia of 1965 (hereinafter referred to as 'Civil

Procedure Code'), art.3 sub verbo "foreign court" and "foreign judgment".

${ }^{9}$ Id., art. 457(b).

${ }^{10}$ Tecle Hagos Bahta (2011), 'Recognition and Enforcement of Foreign Arbitral Awards in Civil and Commercial Matters in Ethiopia', Mizan Law Review, Vol. 5, No.1, pp. 105-139.

${ }^{11}$ Arbitration and Conciliation Proclamation, supra note 7, art. 2(8).
} 
arbitration is mentioned to be outside of the Ethiopian territory. [Emphasis added].

As indicated in the first limb, conventions (treaties) may determine the nationality of arbitral awards. The second limb of the afore-said legal provision clearly states that an arbitral award is 'foreign' if the seat of arbitration is outside of Ethiopia. The approach is further entrenched under Art. 44(3) of the Proclamation. It provides thus:

The award shall state the claim, the material facts in dispute, the name, address and, where necessary, the citizenship of the contracting parties, grounds for rendering the award, the costs of and mode of payment of costs of arbitration, the date of the award, and place of the arbitral award as stipulated under Article 30 of this Proclamation.

The afore-cited legal provision stipulates that it is imperative for the arbitral award to state the place of the arbitral award. Nevertheless, it does not bind foreign arbitral proceedings. It is, therefore, of little help. It is, however, indicative of the deliberate choice by the redactors to deploy the seat of arbitration as the determining criterion for nationality. ${ }^{12}$ This is the geographical criterion. In this regard, as per Article I of the New York Convention, the application of the Convention brings about three types of arbitral awards, namely: foreign, nondomestic and domestic awards. A foreign award is one that falls under the New York Convention and is made outside of Ethiopia; a nondomestic award is an award made in Ethiopia and falls under the Convention; ${ }^{13}$ and, a domestic award is one made in Ethiopia, and, thus, does not fall under the Convention.

The nondomestic awards are a class of arbitral awards, which may be eventuated due to the fact that some states accord nationality not only on the basis of the geographical criterion but also on a procedural basis. The latter means that arbitral awards made in a convention state may be considered 'foreign arbitral award' for the purpose of recognition and enforcement of arbitral awards under the New York Convention. This is because the arbitral

${ }^{12}$ See Id., art.30.

13 Art. I(1) of the New York Convention defines 'foreign arbitral awards' as awards which are made in the territory of a state other than the state in which recognition and enforcement is sought. It also stipulates that the Convention 'shall also apply to arbitral awards not considered as domestic awards in the State where their recognition and enforcement are sought'. 
proceeding took place under the procedural rules of another state. This is the procedural criterion. Rubino-Sammartano aptly noted that: ${ }^{14}$

Confirmation of the procedural criterion can be found in the New York Convention, which, in addition to the first class of awards (those made in other states) treats as foreign a second class of awards, even if made in a state, are the results of proceedings governed by a procedural law different from the law of that state.

Indeed, this is not unheard of as arbitrating parties may choose arbitration rules of a state other than the state where the arbitration proceedings take place. In other words, the lex loci arbitri, apart from its mandatory procedural rules, may not necessarily be the curial law (the lex arbitri). The contracting parties may find it more suitable to have their arbitration proceedings governed under the law of arbitration of a third-country of which nationality some states are willing to accord to the arbitral award. One would, thus, expect that the new Arbitration and Conciliation Proclamation should have encapsulated when and how international commercial arbitrations which take place in Ethiopia may, under certain circumstances, be considered as nondomestic awards and hence falling under the ambit of the New York Convention for their recognition and enforcement in Ethiopia.

The application of the New York Convention seems to have been restrained to the recognition and enforcement of arbitral awards 'made only in the territory of another contracting state.$^{15}$ [Emphasis supplied]. Thus, the possibility of ascribing nationality on the basis of the procedural criterion is ruled out.

\subsection{Multiple enforcement regimes: à la carte}

Currently, subsequent to the coming into force of the New York Convention and the Conciliation and Arbitration Proclamation No. 1237/2021 in Ethiopia, an award-creditor may resort to either of the following recourses for the recognition and enforcement of a foreign arbitral award:

(a) Recourse in accordance with the terms of the New York Convention It should be noted that the terms of the New York Convention are only applicable in relation to an arbitral award concerning commercial matters.

\footnotetext{
${ }^{14}$ Mauro Rubino-Sammartano (2014), International Arbitration: Law and Practice, $3^{\text {rd }}$ Ed., Kluwer Law International, p. 956.

15 Art. 2 of the Convention on the Recognition and Enforcement of Foreign Arbitral Awards Ratification Proclamation No.1184/2021 (hereinafter also referred to as the 'ratification proclamation'.)
} 
This is because the 'commercial reservation' has been registered to the Convention in Ethiopia;

(b) Recourse in accordance with the Arbitration and Conciliation Proclamation No.123/2021

It is worthy to note that this Proclamation is only applicable for arbitral awards concerning commercial matters as stipulated under Art. 3 of the Proclamation. ${ }^{16}$

(c) Recourse in accordance with the Civil Procedure Code provisions under Arts. 458-461

These provisions find application for any arbitral award irrespective of its being civil or commercial matter. Article 461 of the Civil Procedure Code, which deals with the recognition and enforcement of foreign arbitral awards, is repealed by the new Arbitration and Conciliation Proclamation No.1237/2021. However, the new Proclamation only applies to commercial matters. It is not, therefore, clear whether the application of Art. 461 will survive in relation to the recognition and enforcement of foreign arbitral awards relative to civil matters. It is submitted that it should continue to apply lest the recognition and enforcement of foreign arbitral awards on civil matters should be left in limbo. Indeed, the arbitral rules in Civil Procedure Code, including Art. 461, will continue to apply for some time to come. This is envisaged with no equivocation under Art. 77 of the Arbitration and Conciliation Proclamation. Art. 77 of the Proclamation stipulates thus:

(1) Any arbitration agreement signed before the coming into force of this Proclamation shall be governed by the law that had been in force before the effective date of this Proclamation.

(2) Arbitral proceedings initiated before the coming into force of this Proclamation or cases of arbitration pending before courts, ongoing proceedings and execution of decisions shall be governed by the law in force before the coming into force of this Proclamation.

(3) Contracting parties who have concluded arbitration agreement or in the process of concluding an agreement before the coming

16 Art. 3(1) of the Arbitration and Conciliation Proclamation No.123/2021 provides thus:

Without prejudice to the international treaty to which Ethiopia is a signatory, this Proclamation shall apply to commercial related national arbitration, international arbitration whose seat is in Ethiopia and national conciliation proceedings. 
into force of this Proclamation may agree to be governed by this Proclamation.

Art. 77 of the Proclamation is indeed a signpost for arbitrating parties to cautiously pay heed of the date on which the Proclamation enters into force, which is 2 April 2021. The $2^{\text {nd }}$ day of April 2021 is an important cutoff date for all arbitration agreements and arbitral awards which straddle the dates prior to and post the entry into force of the Arbitration and Conciliation Proclamation No.1237/2021.

This also shows that Art. 461 of the Civil Procedure Code will have farreaching repercussions in the future not only in its application to commercial matters, as enunciated under Art. 77 of the Proclamation, but also insofar as non-commercial matters are concerned. Thus, unless the conditions for the recognition and enforcement of foreign arbitral awards on civil matters are set out by legislative dispensation in the foreseeable future, there is no doubt that Art. 461 of the Civil Code will continue to apply.

In this regard, the debate on whether it is the federal or the regional states which possess the legislative jurisdiction to enact on the modus operandi of dispute settlement mechanisms in relation to civil matters lingers on. This extends, inter alia, to issues of arbitrability or nonarbitrability and the recognition and enforcement of both domestic and foreign arbitral awards concerning civil matters. Furthermore, the courts will find a leeway under Art. 79 of the Arbitration and Conciliation Proclamation for so applying. Article 79 stipulates: 'The provisions of the Civil Code that may help the implementation of the conciliation and arbitration proceedings or related to the proceedings and not contravene this Proclamation shall be applicable'.

(d) Recourse in accordance with the terms of a convention to which the country is a party by virtue of Art. 458(1) of the Civil Procedure Code

Article 53(1) of the Arbitration and Conciliation Proclamation states: ' $[w]$ here a foreign arbitral award falls under international treaties ratified by Ethiopia, it may be recognized or enforced in accordance with such treaties' ${ }^{17}$ These conventions can be those that are already ratified by Ethiopia or the conventions which might be ratified in the future. Such bilateral and/ or multilateral conventions have not been ratified by Ethiopia to-date save the Treaty of Judicial Assistance between the Djibouti and

${ }^{17}$ See Arbitration and Conciliation Proclamation, supra note 7, Art. 53(1). 
Ethiopia. ${ }^{18}$ It is not, however, clear whether the recognition and enforcement of foreign arbitral awards are encapsulated under the terms of the said Treaty of Judicial Assistance. The Treaty deals with reciprocal recognition and enforcement of judgments and other evidence related assistances between the two countries. ${ }^{19}$ Thus, seldom has Art. 458(1) of the Civil Procedure Code found application in Ethiopia in terms of both the recognition and enforcement of foreign arbitral awards and judgments.

Moreover, as alluded to above, international conventions are given deference in their applications to the recognition and enforcement of foreign arbitral awards under Art 3 of the Arbitration and Conciliation Proclamation. In this regard, the application of Article VII(1) of the New York Convention is worth noting. It reads:

The provisions of the present Convention shall not affect the validity of multilateral or bilateral agreements concerning the recognition and enforcement of arbitral awards entered into by the Contracting States nor deprive any interested party of any right he may have to avail himself of an arbitral award in the manner and to the extent allowed by the law or the treaties of the country where such award is sought to be relied upon. [Emphasis supplied].

Thus, Article VII of the New York Convention allows the award-creditor to choose more favourable terms stipulated under domestic law than those of the New York Convention in the state where the recognition and enforcement is sought. Whether the terms for the recognition and enforcement of foreign arbitral awards enunciated under Art. 53 of the Arbitration and Conciliation Proclamation are more favourable than the terms of the New York Convention for award-creditors who wish to benefit therefrom are yet to be seen in practice.

In the light of this, an award-creditor may have a spectrum of choices based on which the party may seek for the recognition and enforcement of an arbitral award. In this regard, the following options should be carefully trodden upon by the award-creditor:

(a) For arbitral awards made prior to 22 November 2020 (the date of entry into force of the New York Convention in Ethiopia), one has to rely solely on Arts. 458-461 of the Civil Procedure Code on the recognition and enforcement of foreign arbitral awards.

\footnotetext{
${ }^{18}$ A Proclamation to Ratify the Treaty on Judicial Assistance between the Transitional Government of Ethiopia and the Republic of Djibouti, 31 May 1995.

${ }^{19}$ For more on this, see Tecle Hagos Bahta, supra note 10, pp.126-127.
} 
(b) For arbitral awards made post 22 November 2020, an award-creditor may have the option of resorting to the provisions of the New York Convention or to the domestic rules on the recognition and enforcement of foreign arbitral awards, where the latter are more favourable terms for the party seeking recognition and enforcement of the arbitral award.

(c) For arbitral awards made post 2 April 2021 (the date of entry into force of the new Arbitration and Conciliation Proclamation No.1237/2021), an award-creditor may have the options of choosing between enforcement under the terms of the New York Convention or under the terms of the new Arbitration and Conciliation Proclamation, whichever is the more favourable regime for the enforcement and recognition of the arbitral award.

In order to examine which of the afore-cited two set of rules, under paragraph (c) above, are more favourable for the party, it is good to take note of the grounds of refusal provided for under the Proclamation. Art. 53(2) of the Proclamation provides:

Without prejudice to sub-article (1) of this Article, a foreign arbitral award shall not be recognized or enforced only on the following grounds:

(a) Where it is not based on reciprocity;

(b) Where the arbitral award is based on invalid arbitration agreement or rendered by a tribunal which is not established in accordance with the law of the country in which such award is rendered;

(c) The arbitral award rendered cannot be enforced in accordance with the Ethiopian law;

(d) Where the parties have not had equal rights in appointing the arbitrators or [] in presenting their evidence and getting heard in the course of the proceedings;

(e) Where the matter on which the award is rendered is not arbitrable under Ethiopian law;

(f) Where the arbitral award contravenes public policy, moral and security.

As it presently stands, the first alinea of Article VII(1) of the New York Convention barely finds application as there are currently no bilateral or multilateral agreements which Ethiopia has entered into for the purpose of recognition and enforcement of foreign arbitral awards.

Prior to the coming into force of both the ratification Proclamation and the Arbitration and Conciliation Proclamation, recognition and enforcement of all categories of foreign arbitral awards were sought under Arts. 458-461 
of the Civil Procedure Code. In particular, Art. 461 of the CPC titled "Enforcement of Foreign Awards", under its first sub-article provides the following:

(1) Foreign arbitral award may not be enforced in Ethiopia unless:

(a) Reciprocity is ensured as provided for by Art. 458(a);

(b) The award has been made following a regular arbitration agreement or other legal act in the country where it was made;

(c) The parties have had equal rights in appointing the arbitrators and they have been summoned to attend the proceedings;

(d) The arbitration tribunal was regularly constituted;

(e) The award does not relate to matters which under the provisions of Ethiopian laws could not be submitted to arbitration or is not contrary to public order or morals; and

(f) The award is of such nature as to be enforceable on the condition laid down in Ethiopian laws.

Apart from these requirements, the Civil Procedure $\operatorname{Code}^{20}$ also requires that 'the provisions of the preceding Articles shall apply by analogy when the enforcement of a foreign award is sought'. These provisions to which cross-reference is made through Art. 461(2) are Arts. 456-457 and Arts. 459460 of the Civil Procedure Code. The provisions, in addition to the substantive criteria, set out the procedural and/or formal requirements for the recognition and enforcement of foreign judgments in Ethiopia under the Civil Procedure Code.

These substantive and procedural requirements for the recognition and enforcement of foreign arbitral awards and foreign judgments have been sufficiently dealt with in other previous works elsewhere. ${ }^{21}$ However, Art. 456(1) of the Civil Procedure Code draws our attention as particularly relevant in this context. Art. 456(1) provides "[u]nless otherwise expressly provided for by international conventions, foreign judgments may not be executed in Ethiopia except in accordance with the provisions of this Chapter".

Art. 456(1) is applicable to execution of foreign arbitral awards owing to the cross-reference made under Art. 461(2); and the first limb of Art. 456(1)

${ }^{20}$ Civil Procedure Code, supra note 8, art. 461(2).

${ }^{21}$ Ibrahim Idris Ibrahim (1989), 'Ethiopian Law of Execution of Foreign Judgments', Journal of Ethiopian Law, vol. 19, pp. 17-34; Tecle Hagos Bahta, supra note 10, pp. $105-140$ 
finds application due to the ratification of the New York Convention. Thus, foreign arbitral awards can now be classified into those that should be executed on the basis of the New York Convention and those of Art. 461 of the Civil Procedure Code. The New York Convention finds application only in relation to foreign and non-domestic arbitral awards -concerning commercial matters- made in another convention state. This is owing to the fact that Ethiopia has entered both the commercial and reciprocity reservations.

As indicated above, because of the 'commercial reservation' entered into in Ethiopia, commercial arbitral awards are divided into three; namely, 'foreign arbitral awards', 'non-domestic arbitral awards' and 'domestic arbitral awards'. Domestic arbitral awards find no application under the New York Convention. Therefore, domestic arbitral awards (concerning both commercial and civil matters), foreign and non-domestic arbitral awards concerning civil matters, and foreign arbitral awards made in nonconvention states (concerning both commercial and civil matters) are subject to the conditions set out either under the Civil Procedure Code or the Arbitration and Conciliation Proclamation. This is due to the international nature of the New York Convention and the two reservations registered by Ethiopia in ratifying the Convention.

The second recital of the preamble to the ratification Proclamation sets out the objective of ratifying the New York Convention. It highlights the objective of ratifying the Convention in no uncertain terms that it is to enhance 'foreign investment by boosting [the] country's goodwill in enforcing contracts of foreign parties'. This particular mention of laying down the necessary infrastructure for enforcing foreign contracts in order to boost the country's goodwill with a view to enhance foreign investment merits some discussion here. Indeed, the significance of ratifying international instruments as a means of encouragement for foreign investments has been pointed out under the Common Market for Eastern and Southern Africa (COMESA) Treaty. ${ }^{22}$ Art. 162 of the Treaty provides:

The Member States agree to take necessary measures to accede to multilateral agreements in investment resolution and guarantee arrangements as a means of creating a conducive climate for investment promotion. To this end, the Member States undertake to accede to:

22 Available at $<$ https://www.comesa.int/comesa-treaty-english/ $>$ Last accessed on $20 / 12 / 2021$. 
(a) The International Convention on the Settlement of Investment Disputes between States and Nationals of Other States, 1965;

(b) The Convention Establishing the Multilateral Investment Guarantee Agency; and,

(c) Any other multilateral agreements designed to promote or protect investment.

In the area of investment dispute settlement, arbitration has obviously received the accolades that it is "the most independent and impartial forum in which to make accountable host state abuses, a government's lack of transparency and state discretionary policies that have a negative impact on investors' assets". ${ }^{23}$

It should be noted that Ethiopia has signed about 30 bilateral investment treaties (BITs) and several multilateral investment agreements (MIAs). Such BITs and MIAs provide for substantive and procedural protections to the rights of investors, which in turn, promote and encourage the inflow of capital into the country. The procedural protection includes the dispute settlement mechanisms between investors and the host states; such dispute settlement mechanisms are incorporated in the BITs and MIAs through which the substantive protections are enforced. In this connection, of significant import is the reference of disputes to arbitration under the auspices of the International Center for the Settlement of Investment Disputes (ICSID). ${ }^{24}$

Ethiopia has not yet ratified the ICSID Convention although it has been signatory since 1967. However, the relevance of its ratification of the New York Convention is of paramount importance as it will facilitate the recognition and enforcement of arbitral awards rendered on the basis of the Additional Facility (AF) Rules of ICSID. ${ }^{25}$ It is to be noted that whilst ICSID awards do not invoke the New York Convention for their enforcement, ICSID (AF) awards call for the application of the New York Convention for their recognition and enforcement.

${ }^{23}$ Bernardo M Cremades (2006), 'Resurgence of the Calvo Doctrine in Latin America', 7 Bus. L. Int'l. 53, 72

${ }^{24}$ Convention on the Settlement of Investment Disputes between States and Nationals of Other States (ICSID Convention or the Washington Convention of 1965). Available at https://icsid.worldbank.org/ > Last accessed on 20/12/2021.

25 The Additional Facility (AF) Rules authorize, since 1978, the ICSID Secretariat to administer, inter alia, arbitration and conciliation for the settlement of disputes between states and foreign nationals that fall outside the jurisdictional ambit of the ICSID rules. The AF Rules cater for investment cases in which either the investor's home state or the host state is not a party to the ICSID Convention. 
A scrutiny to the country's bilateral investment treaty (BITs) reveals that the ICSID Additional Facility is invariably placed second amongst the venues for investment arbitration by an investor-claimant whose national state is a party to the ICSID Convention. As noted by Dolzer and Scheurer 'the enforcement of non-ICSID awards, including Additional Facility awards, is subject to the national law of the place of enforcement and to the New York Convention on the Recognition and Enforcement of foreign Arbitral Awards'. ${ }^{26}$ ICSID Convention awards are final and binding as if they were judgments of the national court and cannot be subject to review by national courts. The ICSID Additional Facility awards are, however, fully amenable to the provisions of the New York Convention. Such awards emanate from investment arbitrations and impose pecuniary obligations against the respondent states.

In this regard, the question of state immunity from execution remains in limbo in Ethiopia as there are no judicial or legislative dispensations in this respect. It should be noted that 'the procedure for the enforcement of ICSID awards is governed by the law on the execution of judgments in each country'. ${ }^{27}$ States are classified in their approach to immunity from jurisdiction or execution. ${ }^{28}$ Some states adhere to the absolute immunity that is, immunity for all acts carried out by or on behalf of the state, and others subscribe to the restricted immunity, that is, immunity only for acts jure imperii -acts in its capacity as a state as opposed to those acts in its commercial capacity (acts jure gestionis). The Ethiopian position in this respect is not clear.

\section{3. 'Reservation' under the New York Convention}

\subsection{Non-retroactive application of the Convention}

Article 3 of the ratification Proclamation seems ambiguous. This category of reservation is dubbed as the ' $\mathrm{i}$ ' reservation under the Convention. It allows countries to register a reservation with regards to the (non-) retroactive application of the Convention. ${ }^{29}$ Art. 3 states:

${ }^{26}$ Rudolf Dolzer and Christoph Scheruer (2008), Principles of International Investment Law, OUP, p. 288.

${ }^{27}$ Ibid.

${ }^{28}$ Nigel Blackaby et al (2009), Redfern and Hunter on International Arbitration, $5^{\text {th }}$ ed., OUP, p. 667.

29 The convention states, which have registered such reservation include: Serbia, Croatia, Slovenia, Republic of Moldova, North Macedonia, Montenegro, Bosnia and 
The Convention only applies in the Federal Democratic Republic of Ethiopia with respect to Arbitration Agreements concluded and Arbitral Awards rendered after the date of its accession to the Convention. [Emphasis supplied].

The afore-said legal provision is not devoid of equivocation at least in relation to one aspect. It might have been intended to prescribe that Article II of the Convention finds application only if the arbitration agreements had been concluded prior to the entry into force of the Convention in the country. It is also clear (from the reading of the legal provision) that only arbitral awards which are rendered after the entry into force of the Convention would be amenable to the New York Convention in Ethiopia. It should not, however, be interpreted to mean that the Convention finds application in the country only in relation to arbitration agreements, which have been entered into after the coming into effect of the Convention should recognition and enforcement of a Convention award, which is based on such an agreement, is sought.

Insofar as the recognition and enforcement of Convention awards are concerned, it should not matter whether the arbitration agreement, based on which the said Convention award was rendered, had been entered into prior or after the entry into force of the Convention. It should also be borne in mind that Convention awards -whose arbitral proceedings straddle the period preceding and following the ratification of the Convention- are not adversely affected under Art. 3 of the ratification Proclamation. In other words, Art. 3 should only find application insofar as Article II of the Convention is concerned; that is to say, Ethiopian courts should only grant anti-suit injunction or decline jurisdiction in support of an arbitration proceeding which is based on an arbitration agreement concluded by the parties after the entry into force of the Convention in the country.

It is unfortunate that all arbitration agreements concluded prior to the coming into effect of the Convention in Ethiopia are rendered ineffective in this respect. This is particularly worrisome in the sense that there are plenty of arbitration clauses in commercial, construction and other investment agreements which are concluded between Ethiopian parties [governmental or otherwise] and foreign parties prior to the said date. Ethiopian courts will find it difficult to enforce Article II of the Convention should either of the parties seek to litigate its case in the courts, notwithstanding the valid arbitration agreement between the parties.

Herzegovina, Tajikistan, Seychelles, Sierra Leone, Malta, Malawi. To this list, Ethiopia has been added. 
This could even be more critical as it may also apply apropos arbitration cases pending outside of Ethiopian courts' jurisdiction. The pendency rule in the Civil Procedure Code of Ethiopia is not devised in a manner that can help obviate parallel proceedings in judicial or arbitral litigations. According to Art. 8(2) of the Code "[t]he pendency of a suit in a foreign court shall not preclude the courts in Ethiopia from trying a suit founded on the same cause of action." The above conclusions notwithstanding, it would be grossly unfair to refuse recognition and enforcement of Convention awards merely because an arbitration agreement, on the basis of which the Convention award was granted, was concluded prior to the entry into force of the Convention in Ethiopia.

\subsection{Date of entry into force of the New York Convention in Ethiopia}

For proper and clear implementation of the New York Convention, it is, first of all, necessary to determine the exact date on which it has entered into force. The date on which the New York Convention has entered into force in Ethiopia could be either of the following dates; namely, the date on which the ratification of the Convention was gazetted in the Federal Gazatte, which is 13 March 2020. In this connection, Art. 6 of the said Proclamation states that ' $[\mathrm{t}]$ his Proclamation shall come into force upon publication in the Federal Negarit Gazette'.

Indeed, it has been a long-established practice, save a few exceptions, that legislative enactments in Ethiopia enter into force upon being officially gazetted. ${ }^{30}$ The deferral of the coming into force of the National Building Proclamation No. 624/2009 was, for instance, mainly necessitated by the need to lay the necessary foundations on the ground for its implementation. The setting up of the institutional mechanisms and the setting out of

${ }^{30}$ In this regard, the National Building Proclamation No.624/2009 is worth noting in that it entered into force after one year from the date of its publication on the gazette. The said Proclamation initially contained the usual provision proclaiming that it would come into force on the date of its publication on the official gazette. However, it was immediately rectified by means of Corrigendum No.4/2009, which read thus:

"In this Proclamation the statement under Article 60 stated as 'This Proclamation shall come into force upon the date of its publication in the Federal Negarit Gazeta' shall be read as 'This Proclamation shall come into force after one year from the date of its publication in the Federal Negrit Gazeta'." 
particulars for the modus operandi of these institutions might have called for a moratorium in its application. ${ }^{31}$

One may also question whether the New York Convention might require the necessary preconditions for its implementation in Ethiopia. In this regard, it is evident that Art. 5 of the Proclamation is intended to cater for such eventualities. Art. 5 of the Proclamation provides that the Federal Attorney General (currently Ministry of Justice) "is hereby authorized to undertake, in collaboration with the Ministry of Foreign Affairs and other Government Organs, all acts necessary for the implementation of the Convention." [Emphasis supplied].

Of particular import in this regard is the requirement stipulated under Article XII(2) of the New York Convention. It reads: "For each State ratifying or acceding to this Convention [...], this Convention shall enter into force on the ninetieth day after deposit by such State of its instrument of ratification or accession."

In other words, in order for the New York Convention to enter into force in any ratifying or acceding state, the state must deposit its instrument of ratification or accession to the Secretary-General of the United Nations as per Article IX(2) of the Convention. Secondly, there is a waiting period of 90 days before the Convention will have entered into force in the territory of the ratifying or acceding state. If one takes the assumption that Ethiopia deposited its instrument of ratification on 13 March 2020, the Convention enters into force on 13 June 2020. However, even leaving aside bureaucratic red tapes, this sounds too ambitious.

Art. 5 of the Proclamation entreats the Office of the Attorney-General (currently Ministry of Justice) to, in addition to the Ministry of Foreign Affairs, collaboratively engage unidentified government departments. ${ }^{32}$ In so doing, the legislative provision does not provide for any direction whatsoever as to which departments are to be consulted. Nor is there any mention of the specific matters concerning which collaboration is sought for. It is, therefore, left to be decided by the Ministry of Justice at will. No wonder, thus, that the date of deposit of the instrument of ratification of the Convention for Ethiopia is flagged as 24 August 2020. In essence, it literally

\footnotetext{
${ }^{31}$ In fact, the Council of Ministers Building Regulation No.243/2011, which contained the essential requisites for executing the Proclamation, only came into force on 24 May 2011; it should be noted that those regulations came into force two years later. See Council of Ministers Building Regulation No.243/2011, Federal Negarit Gazeta, Year 17, No.71, 24 May 2011.

32 See the Ratification Proclamation, supra note 15, art.5.
} 
took four months and a half to deposit the instrument of ratification. ${ }^{33}$ Consequently, the official date of ratification is set as of 22 November 2020, which is precisely 90 days from the date of deposit of the instrument of ratification.

Given the variation in the date of entry into force of the New York Convention in Ethiopia, therefore, it is imperative to question as to which date prevails in the application of the New York Convention (that is to say, 13 March 2020 -the date of publication on the official gazette- or 22 November 2020 -official date of registration of the ratification as per the Convention's requirements. The interest at stake is whether an awardcreditor seeking for the recognition and enforcement of an arbitral should be entitled to benefit from the legislative commitment embodied under Art. 6 of the ratification Proclamation No.1184/2020, which proclaimed 13 March 2020 as the effective date of the New York Convention in Ethiopia. A similar concern arises on the part of a disputing party seeking for anti-suit injunction on the basis of a valid arbitration agreement under Article II(3) of the Convention.

There are three reasons to be advanced in favour of the application of the ratification Proclamation. First, the long-held 'pro-enforcement bias' of the New York Convention might cater for this. Secondly, the second recital of the preamble to the Proclamation clearly enunciates the motivations for ratifying the Convention, i.e., boosting the country's goodwill in enforcing international contracts, which, in turn, enhances foreign investment. Apparently, building goodwill amongst foreign investors and international contracting parties presupposes the fulfillment of commitments made in public. One can, therefore, safely argue that the legitimate expectations of international contracting parties will be respected. In this regard, Art. 6 of the ratification Proclamation underpins the legitimate expectation of the parties to international commercial or investment contracts. And thirdly, parties should also be entitled to benefit from the more favourable domestic law.

In this regard, the Ministry of Justice should do more in laying down the precise and necessary infrastructure for the recognition and enforcement of foreign arbitral awards. It should, for instance, identify and address the issues surrounding the production of documents under Article IV of the New York Convention. Article IV sets forth the documentation requirements,

${ }^{33} \mathrm{See}<\mathrm{https}$ //uncitral.un.org/en/texts/arbitration/conventions/foreign_arbitral_awards/status2 > Last accessed on 20/12/2021. 
which should be submitted by the award-creditor to the court in the recognition and enforcement forum. These documents must be attached to the application by the award-creditor. These documents are essentially three: ${ }^{34}$ (i) the duly authenticated original award or a duly certified copy of it; (ii) the original arbitration clause or submission, or a duly certified copy of it; and (iii) a duly certified translation of them into the language of the country where permission to enforce is sought.

On the face of it, the afore-stated requirements may appear to be simple. However, such seemingly simpler provision has given rise to some difficulties in its implementation. One would, for instance, wonder whether, in submitting an arbitration clause, the applicant should produce only the arbitration clause or the entire contract which incorporates it. ${ }^{35}$ The latter approach would mean not only the submission of bulky documents involving complex commercial transactions (for instance, technology transfer agreements or construction contracts or public-private partnership (PPP) agreements or even any mining or petroleum concession contracts) but also the prolix task of translation into the language of the enforcement court. Secondly, there is a need for clearly defining the words 'duly authenticated' and 'duly certified' for the purpose of recognition and enforcement of foreign arbitral awards under the New York Convention. This is so as such terms may convey different meanings and practices from one jurisdiction to another. ${ }^{36}$

For example, the position in India has been stated that the production of a mere photocopy of the award is acceptable provided that this is cured by subsequently filing a duly authenticated copy. ${ }^{37}$ In this respect, Mcllwrath and Savage state that 'authentication' and 'certification' mean different things but both address 'concerns about the genuineness of documents in which enforcement proceedings are based'. ${ }^{38}$ They stated:

${ }^{34}$ Article IV of the New York Convention; Art. 35(2) of the UNCITRAL Model Law on International Commercial Arbitration. Available at

$<$ https://uncitral.un.org/en/texts/arbitration/modellaw/commercial_arbitration $>$ Last accessed on 20/12/2021. See also Art. 51(2) - (4) of the Arbitration and Conciliation Proclamation.

${ }^{35}$ See also Mauro Rubino-Sammartano, supra note 14, p. 952.

${ }^{36}$ Id., p. 954 (wherein Rubino-Sammartano states that such requirements are unfamiliar in an English context save that 'the appropriate form is an affidavit deposing to its authenticity, accuracy as a copy or truth as a translation as the case may be').

${ }^{37}$ Id., p. 955

${ }^{38}$ Michael Mcllwrath and John Savage (2010), International Arbitration and Mediation: A Practical Guide, Kluwer Law International, p. 350. 
Authentication is the process designed to confirm that the original signed document is genuine by having someone of sufficient authority attest to the authenticity of the original [and] certification is similar, but is designed to confirm that a copy faithfully reflects the existence and content of the original. ${ }^{39}$

\subsection{Reciprocity reservation}

Article I(3) of the New York Convention provides that: "[w]hen signing, ratifying or acceding to this Convention, or notifying extension under Article $\mathrm{X}$ hereof, any State may on the basis of reciprocity declare that it will apply the Convention to the recognition and enforcement of awards made only in the territory of another Contracting State." [Emphasis supplied]. The import of this reservation, referred to as the 'reciprocity reservation', is precisely summed up thus: ${ }^{40}$

To the extent that States take advantage of it, the reciprocity reservation has the effect of narrowing the scope of application of the New York Convention. Instead of applying to all foreign awards wherever they are made, the scope of the New York Convention may be limited to 'Convention awards', that is, awards made in a state which is a party to the New York Convention.

Ordinarily, the New York Convention is intended to apply to the recognition and enforcement of foreign arbitral awards made in the territory of any state other than the state where the recognition and enforcement of such awards are sought and of arbitral awards made within the state of enforcement that are not considered by its laws to be domestic awards.

The doctrine of reciprocity is not a new concept in Ethiopia. It has been rearing against those judgment creditors seeking enforcement of foreign judgments in Ethiopia. Its application straddles both the recognition and enforcement of foreign judgments and foreign arbitral awards as per Art. 459(a) and Art. 461(a) of the Civil Procedure Code respectively. ${ }^{41}$ The need for preserving the doctrine of reciprocity has also been expounded by Robert A. Sedler:

${ }^{39}$ Ibid.

${ }^{40}$ Nigel Blackaby et al, supra note 28, p. 635.

41 For more on the concept and application of the reciprocity requirement for the recognition and enforcement of foreign judgments and foreign arbitral awards in Ethiopia respectively, see Ibrahim Idris Ibrahim, supra note 21 and Tecle Hagos Bahta, supra note 10. 
If the courts of [a foreign] country refuse to execute Ethiopian judgments, the Ethiopian court must, in turn, refuse to execute their judgment. In as much as most countries will execute the judgment of other countries, it should be presumed that any country will execute an Ethiopian judgment unless the contrary is proved. ${ }^{42}$

Another writer, however, points out that the doctrine of reciprocity is aimed at retaliation against a state as its basis, but which may simultaneously victimize innocent individuals. ${ }^{43}$ Ironically, the victims of this exercise by certain states may be their own nationals or individuals and bodies corporate domiciled in those countries. It is noted that the doctrine is less pronounced in the recognition and enforcement of foreign arbitral awards than it is in relation to foreign judgments. As Michael McIlwrath and John Savage stated, '[g]iven the large number of states now party to the Convention, this is not as meaningful a restriction as it once was'. ${ }^{44}$

The adoption of the United Nations Commission on International Trade Law (UNCITRAL) as Model Law on International Commercial Arbitration by many states now has rendered the application of reciprocity insignificant. The UNCITRAL Model Law dispenses with the reciprocity requirement for the recognition and enforcement of arbitral awards. ${ }^{45}$ Furthermore, a perusal on the status of the New York Convention reveals that a substantial number of Convention states have ratified the Convention without the reciprocity requirement. Out of the 169 states, 82 have ratified the Convention with the reciprocity reservation. The rest of the member states accord recognition and enforcement of foreign arbitral awards irrespective of whether or not it has been rendered in a convention state.

\subsection{Commercial reservation}

The second reservation permits an acceding or ratifying state to reserve the applicability of the Convention "only to differences arising out of legal relationships, whether contractual or not, which are considered as commercial under the national law of the State making such declaration". ${ }^{46}$ Albert Jan van den Berg states that the inclusion of this reservation was necessary in order to accommodate the interests of the civil law countries. He notes that " $[t]$ this reservation was inserted because at the New York

\footnotetext{
${ }^{42}$ Robert A Sedler (1968), Ethiopian Civil Procedure, HSIU, p. 394.

${ }^{43}$ Ibrahim Idris, supra note 21, p. 24

${ }^{44}$ Michael McIlwrath and John Savage, supra note 38, p. 347

${ }^{45}$ See UNCITRAL Model Law on International Commercial Arbitration, supra note 34, art. 36 .

${ }^{46}$ New York Convention, supra note 4, Article I(3).
} 
Conference of 1958 it was believed that, without this clause, it would be impossible for certain civil law countries, which distinguish between commercial and non-commercial transactions, to adhere to the Convention". ${ }^{47}$

This holds true for Ethiopia not only because it is a civil-law country but also because the compartmentalization of commercial and non-commercial transactions is so important in demarcating the legislative, executive and judicial powers between the federal government and the federated states. This process of demarcation remains yet the uncharted territory in the Ethiopian federal system.

Given the fact that it is not constitutionally clear as to which organ is entitled to define the scope of economic activities to which 'commercial matters' extend, it can be observed that there are three circumstances which militate in favour of wrapping up more activities under the umbrella of 'commercial matters'. Firstly, the federal legislatures' attempt to capture as many economic activities as they arise from time to time. This is done by way of legislative definitions in legal instruments concerning commercial law. ${ }^{48}$

Secondly, the fact that the Federal Supreme Court's Cassation Division is bestowed with the power of cassation over all federal and state matters may tip the scale in favour of the Federal government expanding on its legislative influence on as much economic activities as possible. Thirdly, the power of the Federal government to ratify all treaties (or convention, be it civil or commercial) broadens the scope of the federal legislative power.

In this regard, the Arbitration and Conciliation Proclamation defines 'commercial arbitration' in an illustrative manner. Art. 2(7) of the Proclamation provides:

'commercial related' includes business relationship for the supply and exchange of goods or service, agreement for distribution, commercial agent, lease, construction, consultancy, engineering, license for commercial purpose, investment, finance, bank, insurance, mining, joint venture and other business organizations that are not prohibited by this Proclamation, transportation of persons and goods by air, sea and land includes similar businesses

\footnotetext{
${ }^{47}$ Albert Jan van den Berg (2005), ICCA: New Horizons in International Commercial Arbitration and Beyond, Kluwer Law International, p. 319.

${ }^{48}$ It is noted that, as per art. 55(4) of the Federal Constitution, the power to enact laws relative to 'commercial matters' is expressly provided to the Federal government.
} 
arising from contractual and extra-contractual relations of a commercial nature.

This illustrative (rather than an exhaustive) listing approach to the definition of 'commercial' matters is an innovative devise in order to expand the scope of application of the arbitration law to those economic activities which are evolving as commercial from time to time. ${ }^{49}$ In this regard, the UNCITRAL Model Law on International Commercial Arbitration, ${ }^{50}$ which is placed in a footnote, reads:

The term 'commercial' should be given a wide interpretation so as to cover matters arising from all relationships of a commercial nature, whether contractual or not. Relationships of a commercial nature include, but are not limited to, the following transactions: any trade transactions for the supply or exchange of goods and services; distribution agreement; commercial representation or agency; factoring; leasing; construction of works; consulting; engineering; licensing; investment; financing; banking; insurance; exploitation agreement or concession; joint venture and other forms of industrial or business cooperation; carriage of goods or passengers by air, sea, rail or road.

The Egyptian approach to defining 'commercial' matters seems comparable with Ethiopia's Arbitration and Conciliation Proclamation. Both approaches are also, to a great extent, inspired by the UNCITRAL Model Law on International Commercial Arbitration. And yet this Egyptian Arbitration Law of $1994^{51}$ is said to have expanded the definition of 'commercial 'matters enunciated under the UNCITRAL Model Law. It provides: ${ }^{.2}$

An arbitration is commercial within the scope of this Law when the dispute arises over a legal relationship of an economic nature, whether contractual or non-contractual. This comprises for

${ }^{50}$ See the text of UNCITRAL Model Law on the International Commercial Arbitration, available at

$<$ https://uncitral.un.org/en/texts/arbitration/modellaw/commercial_arbitration> Last accessed on 20/12/2021.

${ }^{51}$ Law Concerning Arbitration in Civil and Commercial Matters, Law No. 27 of 1994, which came into force on 22 May 1994.

52 Id., art. 2. 
example the supply of commodities or services, commercial agencies, construction and engineering or technical know-how contract, the granting of industrial, touristic and other licenses, technology transfer, investment and development contracts, banking insurance and transport operations, and operations relating to the exploration and extraction of natural wealth, energy supply, laying of gas or oil pipelines, building of roads and tunnels, reclamation of agricultural land, protection of the environment and establishment of nuclear reactors.

Two important observations can be made from the afore-said definition of 'commercial' disputes. Firstly, unlike the UNCITRAL Model Law, the definition of 'commercial matters' in the Ethiopian Arbitration and Conciliation Proclamation is a substantive provision and is meant to be merely illustrative and intended to be all-inclusive. ${ }^{53}$ Secondly, unlike the Ethiopian Arbitration Law and the UNCITRAL Model Law, in the Egyptian law the word 'commercial', which is used to describe the nature of the legal relationship covered by it, is replaced with the more expansive word 'economic'. ${ }^{54}$

\subsection{Requirement of formality and national treatment of foreign arbitral awards}

Two important steps in the liberalization of arbitration in the international commercial arbitration are reflected under Articles III and IV of the New York Convention. Article III establishes the national treatment principle for foreign arbitral awards in convention states. In this regard, Article III states:

Each Contracting State shall recognize arbitral awards as binding and enforce them in accordance with the rules of procedure of the territory where the award is relied upon, under the conditions laid down in the following Articles. There should not be imposed substantially more onerous conditions or higher fees or charges on the recognition or enforcement of arbitral awards to which this Convention applies than are imposed on the recognition or enforcement of domestic arbitral awards.

\footnotetext{
${ }^{53}$ Arbitration and Conciliation Working Procedure Proclamation No. 1237 /2021, Article 2(7).

${ }^{54}$ Amazu Asouzu (1996), 'The Egyptian Law Concerning Arbitration in Civil and Commercial Matters', 8 RADIC, p. 145
} 
This provision sets foreign arbitral awards on equal footing with domestic arbitral awards in terms of the enforcement of the foreign arbitral award 'in accordance with the rules of procedure' of the enforcement state. Furthermore, There can be no 'substantially more onerous conditions or higher fees or charges on the recognition and enforcement of arbitral awards to which this Convention applies than are imposed on the recognition and enforcement of domestic arbitral awards'.55

One of the successes of the New York Convention is believed to be the abolishing of the double exequatur. Such a practice necessitated the approval or certification by the rendition forum of the arbitral award of its status as 'final and enforceable' in the place where it is made. ${ }^{56}$ In this regard, Article IV of the New York Convention provides:

1. [...] the party applying for recognition and enforcement shall, at the time of the application, supply

(a) The duly authenticated original award or a duly certified copy thereof;

(b) The original agreement referred to in Article II or a duly certified copy thereof.

2. If the said award or agreement is not made in an official language of the country in which the award is relied upon, the party applying for recognition and enforcement of the award shall produce a translation of these documents into such language. The translation shall be certified by an official or sworn translator or by a diplomatic or consular agent.

In a similar vein, Art. 51 of the Arbitration and Conciliation Proclamation sets out the required documentations accompanying an application for the recognition and enforcement of foreign arbitral awards. An award-creditor should, thus, produce: (a) the arbitration agreement based on which the arbitral award have been rendered; (b) the original award or an authenticated copy of the award; and (c) where the award is rendered in a language different from the language of the executing court, a translation of these documents into the language of the court shall be produced.

It is also required under Art. 51(3) of the Arbitration and Conciliation Proclamation that all documents should be authenticated by the relevant organs. Seen altogether, therefore, it is hoped that the requirements will be interpreted by the enforcing courts in line with the wording and

\footnotetext{
${ }^{55}$ New York Convention, supra note 4, Art. III.

${ }^{56}$ See Civil Procedure Code, supra note 8, Art. 457(b).
} 
interpretation accorded to Article IV of the New York Convention or Art. 35(2) of the UNCITRAL Model Law on International Commercial Arbitration.

Art. 457 of the Civil Procedure Code renders the double exequatur requirement mandatory. It states:

An application for the execution of foreign judgment shall be in writing and shall be accompanied by:

(a) A certified copy of the judgment to be executed; and

(b) A certificate signed by the President or the registrar of the court having given judgment to the effect that such judgment is final and enforceable.

The written application for recognition and enforcement of a foreign judgment must be accompanied by a certified copy of the judgment to be executed and a certificate signed by the court attesting that the judgment is 'final and enforceable'. This equally applies on the recognition and enforcement of foreign arbitral award. One of the main import of the New York Convention is the abandonment of the double exequatur. It is, indeed, a step taken in the right direction that Articles 51-53 of the new Arbitration and Conciliation Proclamation have also abolished the double exequatur.

\section{The Enforcement of Annulled Arbitral Awards in Their Country of Origin}

In the modern practice of arbitration under the New York Convention, none has given rise to a rancorous controversy as to whether there is a possibility of enforcing arbitral awards which are annulled or set aside in the rendition forum. In this regard, Article V(1)(e) of the New York Convention reads:

Recognition and enforcement of the award may be refused ... only if [the party against which the award is invoked] furnishes to the competent authority where the recognition and enforcement are sought, proof that:

(e ) The award has not yet become binding on the parties, or has been set aside or suspended by a competent authority of the country in which, or under the law of which, that award was made ...

This should have given the simple answer to the controversy. However, the recourse to Article VII of the New York Convention by the awardcreditor has opened a window of opportunities in the recognition and enforcement of arbitral awards. As Blackaby et al stated, '[t]he New York 
Convention has long been regarded as being of fundamental importance to the recognition and enforcement of international arbitral awards [and] it remains so' ${ }^{57}$ However, the possibility of obtaining recognition and enforcement of an award that has been set aside in its place (seat) of arbitration or by applying a more favourable local law has mustered momentum in some jurisdictions. Article VII(1) of the New York Convention provides:

The provisions of the present Convention shall not affect the validity of multilateral or bilateral agreements concerning the recognition and enforcement of arbitral awards entered into by the Contracting States nor deprive any interested party of any right he may have to avail himself of an arbitral award in the manner and to the extent allowed by the law or the treaties of the country where such award is sought to be relied upon.

An award-creditor is, thus, entitled to resort to more favourable conditions for recognition and enforcement under a treaty or domestic law of the recognition or enforcing state. Such practices have been successfully made in some jurisdictions. ${ }^{58}$ The United States and France take the lead in this regard. ${ }^{59}$ An award-creditor may, therefore, find it of significant import to peruse the grounds of refusal enunciated under Art. 53 of the new Ethiopian Arbitration and Conciliation Proclamation No. $1237 / 2021^{60}$ in

${ }^{57}$ Negel Blackaby et al., supra note 28, p. 652.

${ }^{58}$ Georgios C. Petrochilos (1999), 'Enforcing Awards Annulled in Their State of Origin under the New York Convention', 48 Int'l \& Comp. L. Q. 856-888.

59 In the matter of the Arbitration of Certain Controversies Between Chromalloy AeroServices and the Arab Republic of Egypt (Chromalloy), 939 F. Supp. 907 (D.D.C., 1996), the U.S. District Court for the District of Columbia recognized and enforced an arbitral award, which was set aside by the Cairo Court of Appeal at its place of arbitration. Subsequently, France has recognized three arbitral awards which were set aside in their place of origin; namely, the Chromalloy case, Hilmarton (which was set aside in Switzerland) and Putrabali (which was set aside in England). For more on this, see Georgios C. Petrochilos, supra note 58; Blackaby et al., supra note 28, pp. 652-653; Georges R. Delaume (1997), 'Enforcement against a Foreign State of an Arbitral Award Annulled in the Foreign State', Int'l Bus. L.J., 253-254.

${ }^{60}$ Art. 53(2) of the Proclamation sets out the grounds for refusal as follows:

"(a) where it is not based on reciprocity;

(b) where the arbitral award is based on invalid arbitration agreement or rendered by a tribunal which is not established in accordance with the law of the country in which such award is rendered;

(c) the arbitral award rendered cannot be enforced in accordance with Ethiopian law; 
contradistinction to the grounds of refusal under Article V of the New York Convention.

\section{Conclusion}

Ethiopia has ratified the New York Convention on the Recognition and Enforcement of Foreign Arbitral Awards of 1958. This indeed opens a new window in the concerted effort towards making Ethiopia an arbitration hub. The ratification of the Convention, coupled with the new Arbitration and Conciliation Proclamation, is indeed a good step in the right direction.

However, there are several challenges in the implementation of the New York Convention. Such challenges include the cleavages in the types of arbitral awards and multiplicity of the enforcement regime owing mainly to the three reservations Ethiopia has registered in the accession to the Convention; namely, the reciprocity reservation, the commercial reservation, and the non-retroactivity reservation. Furthermore, laying the necessary legal and institutional ground for its implementation is imperative. To this effect, the Ratification Proclamation has bestowed the mandate to the Office of the Federal Attorney-General (currently Ministry of Justice).

Finally, due to Article VII of the New York Convention, at least three competing set of rules will find application for the recognition and enforcement of foreign arbitral awards in Ethiopia. These are (i) the New York Convention, (ii) Article 53 of the Arbitration and Conciliation Proclamation, -whenever the award-creditor believes that such set of rules are more favourable to him than the New York Convention; and (iii) Article 361 of the Civil Procedure Code will continue to apply for the recognition and enforcement of foreign arbitral awards that were made prior to the coming into force of both the New York Convention and the Arbitration and Conciliation Proclamation. The Civil Procedure Code will also continue to apply for all civil matters regardless of when such awards are made as neither the New York Convention nor the Arbitration and Conciliation Proclamation applies to civil matters.

(d) where the parties have not had equal rights in appointing the arbitrators or in presenting their evidence and getting heard in the course of the proceedings;

(e) where the matter on which the award is rendered is not arbitrable under Ethiopian law;

(f) where the arbitral award contravenes public policy, moral and security." 
December 2021

\section{Cited References}

Asouzu, Amazu A. (1996). 'The Egyptian Law Concerning Arbitration in Civil and Commercial Matters', 8 RADIC

Asouzu, Amazu A. (2001). International Commercial Arbitration and African States: Practice, Participation and Institutional development, CUP

Blackaby, Nigel et al (2009). Redfern and Hunter on International Arbitration, $5^{\text {th }}$ ed.,

Cremades, Bernardo M (2006). 'Resurgence of the Calvo Doctrine in Latin America', 7 Bus. L. Int'l.

Delaume, Georges R. (1997). 'Enforcement against a Foreign State of an Arbitral Award Annulled in the Foreign State', Int'l Bus. L.J., 253-254;

Dolzer, Rudolf and Scheruer, Christoph (2008). Principles of International Investment Law, OUP

Fekadu Petros (2014). 'The Convention on the Recognition and Enforcement of Foreign Arbitral Awards: Advantages, Disadvantages and some Remarks on Ethiopia's Course of Action Ahead', Mizan Law Review, Vol.8, No.2, 470-483,

Ibrahim Idris Ibrahim (1989). 'Ethiopian Law of Execution of Foreign Judgments', Journal of Ethiopian Law, Vol. 19, pp. 17-34; Tecle Hagos Bahta, supra note 10, 105-140

Mcllwrath, Michael and Savage, John (2010). International Arbitration and Mediation: A Practical Guide, Kluwer Law International

Mesfin Beyene (2019). 'Towards a Better Commercial Arbitration: Should Ethiopia Ratify the New York Convention', Mizan Law Review, Vol.13, No.1, 123-152.

Petrochilos, Georgios C. (1999). 'Enforcing Awards Annulled in Their State of Origin under the New York Convention', 48 Int'l \& Comp. L. Q. 856-888.

Rubino-Sammartano, Mauro (2014). International Arbitration: Law and Practice, $3^{\text {rd }}$ Ed., Kluwer Law International

Sedler, Robert A (1968). Ethiopian Civil Procedure, HSIU

Tecle Hagos Bahta (2011). 'Recognition and Enforcement of Foreign Arbitral Awards in Civil and Commercial Matters in Ethiopia', Mizan Law Review, Vol. 5, No.1, 105-139.

Van den Berg, Albert Jan (2005). New Horizons in International Commercial Arbitration and Beyond (ICCA Congress Series Set) Kluwer Law International 